\title{
Impacts of Cooperative Thrift and Credit Facilities on Members' Business Output in Ogun State, Nigeria
}

\author{
Ezekiel Olaoluwa Akerele ${ }^{1} \&$ Sheriff Adekunle Adekunmbi ${ }^{1}$ \\ ${ }^{1}$ Department of Agricultural Economics and Farm Management, Faculty of Agricultural Management and Rural \\ Development, College of Agricultural Sciences, Olabisi Onabanjo University, Yewa Campus, Ayetoro, Ogun \\ State, Nigeria \\ Correspondence: Ezekiel Olaoluwa Akerele, Department of Agricultural Economics and Farm Management, \\ Faculty of Agricultural Management and Rural Development, College of Agricultural Sciences, Olabisi \\ Onabanjo University, Yewa Campus, Ayetoro, Ogun State, Nigeria. E-mail: akereleeze@gmail.com
}

\author{
Received: September 17, 2017 Accepted: September 29, 2017 Online Published: May 4, 2018 \\ doi:10.5539/sar.v7n3p28 \\ URL: https://doi.org/10.5539/sar.v7n3p28
}

\begin{abstract}
Cooperatives play an important role in facilitating access to credit, procurement and storage distribution of input and marketing of products. They create employment opportunities particularly in the rural areas and allow disadvantaged groups to be organized for social and economic benefit. This study was conducted in Abeokuta North and Abeokuta South Local Government Areas of Ogun State, Nigeria. Both primary data and secondary data were used for the study. Multi-stage random sample was used to sample 108 cooperative members. Data collected were analysed using descriptive tools, budgetary analysis, logit and multiple regression model. The findings shows that majority (50.9 percent) of the cooperators are male, 77.8 percent were married, 59.3 percent were Christians while 98.1 percent were educated. Majority (87.9 percent) had experience ranging from $1-10$ which is good in business. The total variables cost from business was estimated at $\$ 70,983.47$, total fixed cost was $\$ 276,271$ and this accounted for only 79.56 percent of the total cost. Returns on Investment (RRI), Profitability Index (PI), Return on Variable Cost (RRVC) and Operation Ratio (OR) were 181.62\%, 0.63, 173.42\% and 0.21 respectively. Also some (48.1 percent) of the respondents enjoyed loan benefit, while 40.7 percent enjoyed business improvement benefit. The results showed that start up capital, labour and credit obtained were significant to cooperative members'access to credit. The result revealed that majority ( 72.2 percent) of the respondents suffered from non-remittance of deduction by the government as their own challenges. The study concluded that cooperative credit societies is very productive and effective in helping members achieving their goals and also improve their standard of living. Cooperatives societies should encourage members in quick accessibility to loan.
\end{abstract}

Keywords: business, cooperative, logit, multiple regression and credit

\section{Introduction}

International Co-operative Alliance (ICA) (1895) defined Cooperative Society as an autonomous association of persons united voluntarily to meet their common economic, social and cultural needs and aspirations through a jointly owned and democratically controlled enterprise. Also, Ebonyi and Jimo (2002) described cooperative societies as associations of persons who have voluntarily come together to achieve common objectives through the formation of democratically controlled organization; making equitable contributions to the capital required and accepting a fair share of the risk and benefits of the undertakings. UWCC, (2002) summarily described Cooperative Society as a business or group enterprise that is voluntarily owned and controlled by its members, patron and operated for them on a non-profit or cost basis.

The essence of cooperatives as observed by Dogarawa (2005) is an effective way for people to exert control over their livelihoods; provide a unique tool for achieving one or more economic goals in an increasingly competitive global economy; own what might be difficult for individuals to own or pursue by their efforts; strengthen the communities in which they operate through job provision. Generally, cooperative provides an economic boost to the community. This cooperation to Audu et. al., (2007) enables people to achieve through joint efforts, what they are unable to achieve while working as individual.

Unavailability of funds to rural dwellers has been consistently reported in extant literatures and researches to be 
a hindrance to rural productive ventures (Ekong 2007; Aremu, 2004; Ndifon, 2012). Cooperative societies therefore have the enormous potentials to address these issues. Afolabi (2008) elucidated that group efforts are necessary to bring people together so that they can use pooled resources to produce. Cooperative societies are therefore veritable instruments to use in achieving this goal. The ILO report in 2001 and Mukarugwiza (2010), characterized cooperative societies as having the potentials for economic, social and political development of their members. According to the ILO (2001), the economic role of cooperative involves provision of opportunities for improved incomes to members as well as tool to help alleviate poverty. Cooperatives play an important role in facilitating access to credit, procurement and storage distribution of input and marketing of products, these create employment opportunities particularly in the rural areas and allow disadvantaged groups to be organized for social and economic benefit.

According to Brawerman et al., (1991); Gertler, (2001); Dogarawa, (2005); Gibson, (2005); Berko, (2001) craft and artisans cooperatives have the ability to develop rural economy and improve the socio-economic conditions of its members. Because of this, there has been considerable expectation from these cooperatives to achieve social and economic goals and also spur development and alleviate poverty. It is against this background that various Micro and Small Scale Enterprises (MSEs) have grouped themselves for greater efficiency and effectiveness through mutual cooperation.

Thrift and Credit Societies are member-based organizations that help members to address economic problems. They are not banking institutions because of their goal. The ultimate goal is to encourage thrift among the members and to meet credit needs of people who might otherwise fall prey to loan sharks and other predatory lenders (Babatunde et. al., 2007).

Cooperative societies are widely spread organization in developing countries, they are known for strong commitment of, as well as participation in the decision making of their members (Haan et al., 2003).

These societies mobilize local savings and administer credit to members, thereby encouraging thrift and entrepreneurial activity. When first started, credit cooperative use relatively unsophisticated administrative practices, so that the costs are very small and most interest income from loans may either be distributed to the members or reinvested in the credit cooperative within a capitalization programme. Consequently, they can be set up in poor communities, where access to means of secure savings and to credit at non-exploitative terms is of greatest importance (UNDESA, 1999).

The vision of the cooperative development policy of the government, as expressed by the Federal Ministry of Agriculture and Rural Development is to promote members' entrepreneurial capacities so that they can generate adequate surpluses for themselves and create opportunities for economic progress for the public. Asaolu (2004) described cooperative societies as popular organizations which are voluntary associations set up by citizens in order to promote their common welfare. This is because; according to Lawal (2006) Cooperative Society is a kind of business for the benefit of its members. It is a general view that solution to economic problems lies in the human factor; and that more can be accomplished when people coordinate their efforts with each other and take concerns and talents of other into considerations. Reeves (2003) opined that creating wealth requires that we cooperate with each other to make the most valuable use of our limited time, effort and resources, and that human progress can continue to be made through, communication, coordination and cooperation.

The micro-finance power of cooperative societies cannot be overemphasized. Small scale enterprises (SSEs) have been promoted greatly by Micro-finance Institutions (MFI's), the major and most geographically spread of which are cooperative societies. Apart from ready access to micro-credits, Small Scale Enterprises (SSEs) obtain loans with soft and convenient term. Adelaja (2006) noted that the current banking consolidation programme though desirable, is likely to be more of threat than opportunity for MSMEs. Therefore there is the need to embrace the cooperative options. Most members of cooperative societies engage in one economic activity or the other and thus contribute in no small measure to economic outputs of the nation. Economic development is better achieved through cooperation to solve the problem of scarcity.

There have been many misconceptions and opinions from individuals, small and medium business enterprises and corporate business entities that microfinance institutions have outlived their relevance in the twenty first century with the proliferation of larger commercial banks that provide a wide range of financial services due to their sophisticated infrastructure, technology and innovations (Philip, 1993).

However, there are other schools of thought that agitate that micro-finance institutions such as Credit Cooperative are still relevant in the twenty first century. Though large commercial banks provide wider coverage and larger volumes of financial services to their clientele but such services are mainly confined to larger commercial and industrial sectors. Thus, their services are not defused in the hinterland (Darko, 2005). 
Again in as much as traditional banks are perceived to provide needed financial services to individuals, small and medium scale enterprises (SME's) access to credit facilities remains a formidable constraint to most small scale business. Not only accessibility to credit but where they are made available, their inadequacies, high cost of borrowing pose a great challenge to many small scale businesses in due to predominant agrarian economic activities that most people engage in. It is against this background that this study investigated the effect of Cooperative Thrift and Credit Facilities on members' business performance.

\section{Objectives of the Study}

The major objective of this study is to examine the Impacts of Cooperative Thrift and Credit Facilities on Members' Business Output in Ogun State. The specific objectives are to:

(i) examine the cost-return structure of the business of the respondents.

(ii) identify the factors that determine the profit of the members' business.

(iii) examine the factors affecting members access to credit facilities.

\section{Research Methodology}

\subsection{Study Area}

The study was conducted in Abeokuta North and Abeokuta South Local Government Areas of Ogun State. The State comprises Four Divisions which are Egba, Ijebu, Remo and Yewa. The State has 20 Local Government Areas. Abeokuta South Local Government Area of Ogun State created through a Local Government Edict. No 9 of 1976, with its headquarters in Ake. The Local Government Area lies in the rain forest zone of Nigeria. Its lies within latitude $6^{0} 55^{1} 7^{0} \mathrm{~N}$ and longitude $3^{0} 46^{1}-4^{0} 15^{0} \mathrm{E}$, and has human population of about 2,236,689. Abeokuta South Local Government Area is one of the twenty Local Government Areas in Ogun State which lies in the western part of Nigeria. (NPC Report, 2006).

\subsection{Sources and Methods of Data Collection}

Both primary data and secondary data were used for the study. Personally administered questionnaire were used to collect data from a random sample of 108 cooperative members spread across 18 randomly selected cooperative societies covered by the study. Supplementary data were also obtained from secondary sources, including research journals, CBN Statistical Bulletins, FAOSTAT, and the Internet.

\subsection{Sampling Techniques}

Multistage random sampling technique was used in sampling the respondents. In the first stage two (02) Local Government Areas (i.e Abeokuta South and Abeokuta North) was purposively selected. The second stage involves random selection of nine (09) cooperative societies from each of the Local Government Areas to make eighteen (18) cooperative societies and the final stage includes random selection of six (06) cooperators from each of the eighteen (18) societies chosen in the second stage, thus making the total respondents of one hundred and eight (108) respondents used for the research work.

\subsection{Methods of Data Analysis}

In analyzing the data obtained for the study, a number of analytical methods was employed and these include; descriptive statistics, budgetary analysis, regression and the Logit regression model.

\subsection{Analytical Techniques}

\subsubsection{Socio-Economic Characteristics of Small-Scale Business Owners in the Study Area}

Descriptive Statistics: This includes the use of means, frequency and percentage tables. This was used to present information on respondents' socio-economic variables such as age, sex, household size and business experience

\subsubsection{Cost and Return Structure of Small Scale Business Owners in the Study Area}

\section{Budgetary Analysis}

The gross margin of an enterprise is the difference between the total value of production and the variable cost.

Gross Margin can be expressed mathematically as;

Gross Margin Analysis: The budgetary technique was used to determine the gross margin at various scales of operation as earlier used by Asaolu (2004)

Model used in estimating the Gross Margin is: 


$$
\begin{gathered}
\text { GMI }=\Sigma \text { TR }-\Sigma \text { TVC } \\
\text { TR }=\text { Py } . Y i \\
\text { TVC }=\text { Px. X } \\
\text { TC }=\text { TVC }+ \text { TFC } \\
\text { NFI }=\text { GM }- \text { TFC }
\end{gathered}
$$

Where:

GMI $=$ Gross Margin Income $(\mathrm{N})$

$\mathrm{TR}=$ Total Revenue $(\mathrm{N})$

TVC $=$ Total Variable Cost $(\mathrm{N})$

$\mathrm{TC}=$ Total Cost $(\mathrm{N})$

$\mathrm{NFI}=$ Net Income $(\mathrm{N})$

$\mathrm{Py}=$ Unit Price of Output Produced $(\mathrm{N})$

$\mathrm{Y}=$ Quantity of Output $(\mathrm{Kg})$

$\mathrm{Pxi}=$ Unit Price of Variable Inputs Used $(\mathrm{N})$

$\mathrm{Xi}=$ Quantity of Variable Inputs $(\mathrm{Kg})$

Rate of return on Investment $(\mathrm{RRI})=\mathrm{NI} / \mathrm{TC} X 100$

Rate of Return on Variable Cost $(\mathrm{RRVC})=(\mathrm{TR}-\mathrm{TFC}) / \mathrm{TVC} \mathrm{X} 100$

Operating Ratio $(\mathrm{OR})=\mathrm{TVC} / \mathrm{TR}$

\subsubsection{Benefits of Credit Cooperative to Members}

Descriptive Statistics: was used to describe the benefits of credit cooperative to members business. This included the use of means, frequency and percentage tables.

\section{Examine the determinants of business profit of the cooperative members}

Production functions were fitted into the data to examine the determinants of profitability of the investment among cooperative members. The implicit form of the linear regression model used is:

$$
\begin{aligned}
& \text { Implicit form: } Y=\beta_{0}+\beta_{1} X_{1}+U \\
& \text { Explicit form: } Y=\beta_{0}+\beta_{1} X_{1}+\beta_{2} X_{2}+\beta_{3} X_{3}+\beta_{4} X_{4}+\beta_{5} X_{5}+\beta_{6} X_{6}+\beta_{7} X_{7}+\beta_{8} X_{8}+U
\end{aligned}
$$

Where:

$\mathrm{Y}=$ Dependent variable

$\beta_{0=}$ Constant

$\mathrm{Xi}=$ Co-efficient of Independent Variables

$\mathrm{U}=$ Error term

$\mathrm{Y}=$ Total profit $(\mathrm{N})$

$\mathrm{X}_{1}=\operatorname{Gender}(1=$ male, $0=$ female $)$

$\mathrm{X}_{2}=$ Educational level (years of formal schooling)

$\mathrm{X}_{3}=$ Start- up Capital (

$\mathrm{X}_{4}=$ Labor (mandays)

$\mathrm{X}_{5}=$ Age of SMEs owner (years)

$\mathrm{X}_{6}=$ Business experience (years)

$\mathrm{X}_{7}=$ Family size (number)

$\mathrm{X}_{8}=$ Amount of credit obtained ( $)$

$\mathrm{X}_{9}=$ Membership of cooperative society

$\mathrm{U}=$ Error term 
3.5.4 Factors Affecting Members Access to Credit Facilities in the Study Area

\section{The Logit Regression Model}

This was used to determine the socio-economic factors affecting cooperative members' access to credit. This is mathematically stated thus:

$$
\mathrm{L} 1=\mathrm{In}[\mathrm{p} 1 / 1-\mathrm{p}]=\beta_{\mathrm{o}}+\beta_{1} \mathrm{X}_{1}+\beta_{2} \mathrm{X}_{2}+\beta_{3} \mathrm{X}_{3}+\beta_{4} \mathrm{X}_{4}+\beta_{5} \mathrm{X}_{5}+\beta_{6} \mathrm{X}_{6}
$$

Where $\mathrm{Pi}=1$ if respondent had access to credit

$\mathrm{Pi}=0$ if respondent had no access to credit

$\mathrm{X}_{1}=$ Age of respondents in years

$\mathrm{X}_{2}=$ Education in years spent in schools

$\mathrm{X}_{3}=$ Membership of cooperative society

$\mathrm{X}_{4}=$ Occupation ( 1 if employed, 0 if otherwise)

$\mathrm{X}_{5}=$ Gender ( 1 for male, 0 if otherwise)

$\mathrm{X}_{6}=$ Ownership of tangible Asset (house, large areas of land, motorcycle, vehicle e.t.c)

$\mathrm{X}_{7}=$ Household size (Number of person) 


\section{Results and Discussion}

Table 1. Distribution of Sampled Cooperative Members' Household by Socio-Economic Characteristics, N =108

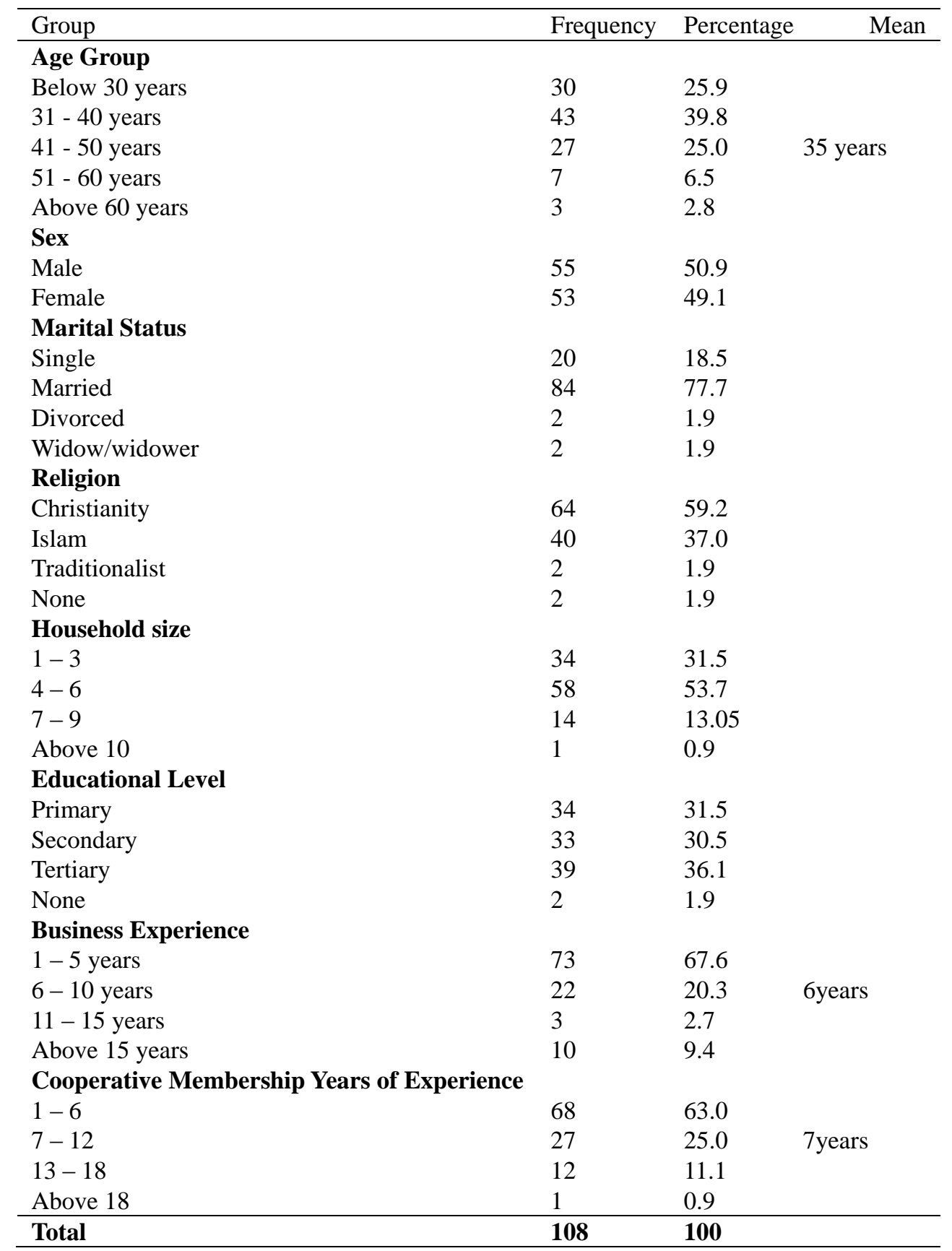

Source: Field Survey, 2015

\subsection{Description of Socio - Economic Characteristics of Cooperative Members'}

In Nigeria, Socio-economic characteristics are important in securing and using credit. The variables discussed include age, gender, marital status, religion, household size, education, business experience, labour used, occupation, cooperative membership experience, credit requested, credit granted and credit obtained among others, as these variables are set to have direct or indirect influence on the performance and decision making activities of the members.

The distribution of age, sex, marital status and religion of respondents is presented in Table 1. Cooperative requires the involvement of agile, productive and able - bodied people in most business activities. Younger people are expected to be able to do more work than older ones. From the survey the age of the respondents 
wasrevealed mean of 35 years. A total of $90.7 \%$ of the respondents were with the age range of 18 to 50 years, this result shows that Cooperative credit enhance their performance. Also, they are expected to be very active and desirous for performance -oriented opportunities (Olarinde et al 2004).

From the findings, the distribution of the sampled household heads of respondents by sex showed that majority (50.9 percent) are male and others (49.1 percent) are female. This implies that both female and male cooperators are well represented and give room for gender equality for effective running and performance. The distribution of respondents according to marital status shows that 77.8 percent of the respondents were married. It also suggests that they would be desirous of opportunities that could be applied towards increasing their income earning capacity and improving their standard of living. The religion distribution of the household head showed that 59.3per cent are Christian while 37.0per cent are Muslims, this implies that most of the respondents are religious and this could aid their credit repayment as at when due.

Data in Table 1 also presents the household size of the respondents; this comprises their wives, children and their dependants. In African setting, women and children labour constitute significant source to labour for small-scale business. The findings revealed that the mean household size 5 persons. It also shows that majority (99.1 percent) of their household members range from 1 to 9 . This implies that the larger the number of household size, the higher the source of labour through family and cooperative credit beneficiaries better in performance. This suggests that as the household size increased the more tendencies for cooperative members to diversify against risk and make way for increased performance by involving family members.

Education is an indispensable tool needed to enhance technical advancement in using cooperative facilities; it plays prominent roles in eradication of ignorance. The findings revealed that large proportion (98.1 percent) of the cooperative members had one form of education and the other. This implies that majority of them would be quick adopter of innovation and equally improve their standard of living.

Business experience plays a dominant role in managing risks associated with the business. The experience gained by respondents as measured by the numbers of years the cooperative members has been into business has bearing on their resources used and overall management of their business activities. The findings revealed that majority ( 87.9 percent) had experience ranging from $1-10$ years which is good in business.

The findings also revealed that majority of the cooperative members have long stayed in cooperative, this thereby assist in their various operation in cooperative activities. The result shows that 63.0 percent had experience between $1-6$ years which could be good in cooperative activities and management.

\subsection{Description of Cost and Return to Cooperative Members}

Budgetary Analysis result from business of the cooperative credit members is presented in Table 2. The total variables cost from business was estimated at $\$ 70,983.47$. The total fixed cost was estimated at $\$ 276,271.00$ and accounted for 10.26 percent of the total revenue. This showed that fixed cost constituted the larger proportion of cost of business for the respondents. In addition, Total Revenue (TR), Gross Margin (GM) and Net Farm Income (NFI) of the business were estimated at $\$ 973,533.33$, $\$ 702,549.87$ and $\$ 426,278.87$ respectively. The result shows that Rate of Returns on Investment (RRI), Profitability Index (PI), Rate of Return on Variable Cost (RRVC) and Operation Ratio (OR) were $181.62 \%, 0.63,173.42 \%$ and 0.21 respectively. The implication of this is that cooperative credit beneficiaries made profit in their businesses and which invariably increased their performance and involvement in cooperative activities. 
Table 3. Estimate of Cost and Returns of Cooperators' staple foods and related items

\begin{tabular}{lcc}
\hline Inputs & Mean cost (N) & \% Total cost \\
\hline Packaging materials cost & $4,263.33$ & 1.23 \\
Transportation cost & $2,390.00$ & 0.69 \\
Levy & $3,788.89$ & 1.09 \\
Labour cost & $14,150.36$ & 4.07 \\
Electricity cost & $4,791.11$ & 1.38 \\
Total Variable Cost & $70,983.47$ & 20.44 \\
Rent cost & $116,021.11$ & 33.41 \\
Scale cost & $2,518.89$ & 0.73 \\
Generator cost & $31,505.56$ & 9.07 \\
Furniture cost & $5,331.11$ & 1.54 \\
Total Fixed Cost & $276,271.00$ & 79.56 \\
Total Cost & $347,254.47$ & \\
Total Revenue & $973,533.33$ & \\
Gross Margin & $702,549.87$ & \\
Net Income & $426,278.87$ & \\
Profitability Indices: & & \\
Rate of Returns on Investment (\%) & $181.62 \%$ & \\
Profitability Index or Return on Sale & 0.63 & \\
Rate of Return on Variable Cost (\%) & $173.42 \%$ & \\
Operating Ratio & 0.21 & \\
\hline
\end{tabular}

Source: Field Survey, 2015

\subsection{Description of Benefits of Credit Cooperative to Members of the Societies by Respondents}

Cooperative as an autonomous association of person who come together on the basis of equality for the purpose of economic growth and betterment of members and self-help are active in the area of advancing credit to members (Adegeye and Dittoh, 1995).

The purpose for which loan is obtained however determine the benefit members enjoy from the socieities.Table 3 presents the various benefit cooperatives members enjoyed. The result revealed that majority (48.1 percent) of the respondents enjoyed loan benefit, while 40.7 percent enjoyed business improvement benefit, 9.3 percent enjoyed savings and dividend benefits and 1.9 percent enjoyed purchase of household commodities benefit. The members are therefore enjoined to use the loan for the purpose for which it is collected and avoid diversion so as to increase quick repayment.

Table 3. Description of Benefits of Credit Cooperative to Members' of the Societies by Respondents

\begin{tabular}{lcc}
\hline Variables & Cooperative Credit Beneficiaries \\
\hline Members' Benefit & Frequency & Percentage \\
Improve Business & 44 & $\mathbf{4 0 . 7}$ \\
Loan Benefits & 52 & 48.1 \\
Dividends & 10 & 9.3 \\
Purchase of Household Commodities & 2 & 1.9 \\
Total & $\mathbf{1 0 8}$ & $\mathbf{1 0 0}$ \\
\hline
\end{tabular}

Source: Field Survey, 2015

\subsection{Description of Estimates of Business Performance of Cooperative Members}

Based on the $\mathrm{R}^{2}$, F-value, $\mathrm{t}$-statistic and theoretical expectation of the variables, the linear function was chosen as lead equation. Table 4 shows the regression estimates for the determinants of factors affecting effect of credit on cooperative members' business in the study area. The findings revealed that $86.5 \%$ and $61.3 \%$ of the variation of credit beneficiaries and non-beneficiaries members respectively were explained by the independent variables included in the model. The F-statistics (61.316) confirmed the suitability of the overall regression equation. The results revealed that three (start up capital, labour and credit obtained.) of the nine variables included in the model were significant at $1 \%$ and 5\% respectively. The results obtained indicated that they are more resourcefully efficient than the non-credit beneficiaries. This is expected and pointed to the positive impact of 
cooperative credit on members' business performance. The variables used had direct relationship with members' business performance. The negative sign of the business experience variable may be due to the fact that the higher the level of experience may lead to familiarity and they may not likely cater for their business.

Table 4. Regressions Estimate of Factors of Business Performance

\begin{tabular}{llll}
\hline Variable Code & \multicolumn{1}{c}{ Variable Name } & Regression Coefficient & \multicolumn{1}{c}{ T-Value } \\
\hline$\beta \mathrm{o}$ & Constant & 75509 & 0.213 \\
$\mathrm{X}_{1}$ & Gender & 0.2433 & 0.136 \\
$\mathrm{X}_{2}$ & Educational Level & 892.8 & 1.182 \\
$\mathrm{X}_{3}$ & Start-up Capital & 1.090 & $10.855^{* * *}$ \\
$\mathrm{X}_{4}$ & Labour & 0.34779 & $1.716^{*}$ \\
$\mathrm{X}_{5}$ & Age & 0.17836 & 0.136 \\
$\mathrm{X}_{6}$ & Business Experience & 0.4469 & -0.795 \\
$\mathrm{X}_{7}$ & Family Size & 0.4917 & 1.616 \\
$\mathrm{X}_{8}$ & Amount of Credit Obtained & 0.069 & $13.528^{* * *}$ \\
$\mathrm{X}_{9}$ & Membership of Cooperative & 11596 & \\
Variance Parameters & & \\
Multiple R $^{2}$ & $=$ & 0.865 & \\
Adjusted $\mathrm{R}^{2}$ & $=$ & 0.851 & \\
$\mathrm{~F}-$ Value & $=$ & $61.316^{* * *}$ & \\
\hline
\end{tabular}

Source: Field Survey, 2015

***Significant at $1 \%$;* Significant at $5 \%$; *Significant at $10 \%$ respectively.

\subsection{Description of the Logit Model Explaining the Factors Affecting Credit Access}

The Logit regression model was used to examine factors that determine cooperative members' access to loan. It measured the parameters of the conditional probability of having access to the required level of funds and marginal changes in explanatory variables on the performance measures. The regression parameters and diagnostic statistics were estimated using Maximum Likelihood Estimation (MLE) technique. Table 5, presents the determinants of cooperative credit acquisition. The findings showed that one of the seven included regressors has significant influence on the cooperative members'access to credit. The chi-square $\left(\sigma^{2}\right)$ value was 27.185 , with a p-value of less than 0.01 and log likelihood function-52.571. Hence, sigma square was statistically significant, thus indicating that the model displays a good fit. The models also met the parallelism assumption that requires that parameters in the subsequent equations are the same. The link test also revealed that the model was correctly specified.

The variable that had significant co-efficient is occupation $\left(\mathrm{X}_{4}\right)$. It should be noted that a positive sign on a parameter indicated that higher values of the variables tend to increase the likelihood of credit accessibility and impact on business performance. Similarly, a negative value of a co-efficient implied that higher values of the variables would reduce the probability of credit accessibility and impact on the business performance. Specifically five of seven variables were positive while the rest are negative.

Hence, occupation should attract topmost importance on the priority list of cooperative members.

Table 5. Logit Model Explaining the Determinants of Credit Acquisition of Cooperative Members

\begin{tabular}{llll}
\hline Variables & Maximum Probability Coefficients & Standard Error & Marginal Effects \\
\hline Constant & $1.217(2.148)$ & 0.437 & -0.915 \\
Age $\left(\mathrm{X}_{1}\right)$ & $0.4283(0.979)$ & 0.437 & 0.8805 \\
Years in Education $\left(\mathrm{X}_{2}\right)$ & $0.4290(0.552)$ & 0.7774 & -0.6250 \\
Membership of Cooperative $\left(\mathrm{X}_{3}\right)$ & $0.1202(1.485)$ & 0.8096 & -0.1248 \\
Occupation $\left(\mathrm{X}_{4}\right)$ & $0.4293(4.288)^{* * *}$ & 0.1001 & -0.1514 \\
Gender $\left(\mathrm{X}_{5}\right)$ & $-0.1100(-0.116)$ & 0.9463 & 0.3432 \\
Asset $\left(\mathrm{X}_{6}\right)$ & $0.2310(1.604)$ & 0.1440 & 0.7618 \\
Household Size $\left(\mathrm{X}_{7}\right)$ & $0.8519(-0.703)$ & 0.1212 & 0.9291 \\
\hline
\end{tabular}

Chi - square value $\left(\sigma^{2)}=14.467 * * * ; \mathrm{P}<0.01\right.$ (significant at $\left.1 \%\right)$; Log likelihood Value $=-59.571$ 
Source: Field Survey, 2015

*** Significant at $1 \% ; * *$ Significant at $5 \% ; *$ Significant at $1 \%$; T-value are in parenthesis

\subsection{Description of Challenges Faced by Members of the Societies by Respondents}

Challenges faced by the cooperative societies' members are numerous but from the study the following were deduced. From the findings, Table 6 presents the various challenges of cooperatives members' of the societies. The result revealed that majority (72.2 percent) of the respondents suffered from non-remittance of deduction by the government as their own challenges; while 14.8 percent had challenges of delay in loan approval; 11.1 percent had insufficient funds as their peculiar challenges and 1.9 percent had overdue loans as their peculiar challenges. It implies that individual societies have various challenges they encountered before loan can be approved and granted to their members.

Table 6. Description of Challenges faced by Members of the Societies by Respondents

\begin{tabular}{lcc}
\hline Variables & Members' challenges \\
\hline Members' Challenges & Frequency & Percentage \\
Non remittance of deduction by the government & 78 & $\mathbf{7 2 . 2}$ \\
Delay in loan approval & 16 & 14.8 \\
Insufficient funds & 12 & 11.1 \\
Overdue loans & 2 & 1.9 \\
Total & $\mathbf{1 0 8}$ & $\mathbf{1 0 0}$ \\
\hline
\end{tabular}

Source: Field Survey, 2015

\section{Conclusion and Recommendations}

In conclusion, Abeokuta metropolis of Ogun State was purposively selected owing to their cooperative involvement. The respondents were selected through cooperative societies but data from one hundred and eight respondents were used for the purpose of analysis. Descriptive statistics, frequency table, percentage, mean, linear regression and logit models were used for the analysis of the data collected.

This showed that fixed cost constituted the larger proportion of cost of business for the respondents. In addition, Total Revenue (TR), Gross Margin (GM) and Net Farm Income (NFI) of the business were estimated at $\$ 973,533.33,, \$ 702,549.87$ and $\$ 426,278.87$ respectively. The result shows that returns on investment (RRI), profitability index (PI), Rate of Return on Variable Cost (RRVC) and Operation Ratio (OR) were 181.62\%, 0.63, $173.42 \%$ and 0.21 respectively. The implication of this is that cooperative credit beneficiaries are business are profitable. The purpose for which loan is obtained however, determines the benefit members enjoy from the societies. The study revealed that cooperative credit societies is very productive and effective in helping members achieving their goals and also improve their standard of living. Looking at the results it was deduced that joining cooperative societies will enhance the welfare of members and likely boost their business profitably.

From the study, the following policy options are recommended

(i) Government should be ready to remit cooperative deductions to their necessary accounts.

(ii) Cooperative societies should encourage members to have quick accessibility to loan.

(iii) Cooperative members should be faithful to repay their overdue loans.

(iv) Government should provide viable means of assisting cooperative societies to improve their management activities.

\section{References}

Adelaja, B. (2006). The Effect of Cooperative Thrift and Credit Societies on Personal Agency Belief: A Study of Entrepreneurs in Osun State, Nigeria. Unpublished.

Afolabi, J. A. (2008). Analysis of loan repayment among small scale farmers in south western Nigeria - a discriminant approach. Journal of Social Science, 17(1), 83-88.

https://doi.org/10.1080/09718923.2008.11892637

Aremu, M. A. (2004). Small Scale Enterprises: Panacea to Poverty Problem in Nigeria. Journal of Enterprises Development, 1(1), 1-8. 
Asaolu, T. O. (2004). Evaluation of the Performance of the Cooperative Investment and Credit Societies (CICS) in Financing Small-Scale Enterprises (SSEs) in Osun State, Nigeria.

Audu, S. I., Salui, O. J., \& Enefola, F. O. (2007). Savings Mobilization by Cooperative Societies in Abaji Local government Area of Kogi State, Nigeria. Patnsuk journal, 3(2), 1-10.

Berko, S. Y. (2001). Agricultural Producer Co-operatives and Agricultural Development in Nigeria. Journal of Cooperative Economics and Management, 1(1), 54-89.

Braverman, A., Guasch, J. L., Huppi, M., \& Pohlmeier, L. (1991). Promoting Rural Cooperatives in Developing Countries: The Case of Sub-Saharan Africa. Washington, D.C World Bank Discussion Papers.

Braverman.A., Guasch, J, L., Huuppic, M., \& Poulmeier, L. (1991). Promoting Rural Co-Operative In Developing Countries: The Case of Mediterranean Journal of Social Sciences MCSER Publishing, Rome-Italy Vol. 5 No 2 January 2014489 Sub-Saharan Africa. World Bank discussion paper: 121. Washington, D. C.: World Bank.

Darko, E. O. (2005). Reality of life, have control over your life, it is for you alone.

Dogarawa, A. (2005). The Role of Cooperative Societies In Economic Development. MPRA paper No. 23161. Available online at: http://mpra.ub.unimuenchen.de/23161. Retrieved on: August 27, 2012.

Ebonyi, V., \& Jimo, O. B. (2002). Cooperative Movement: A Way Out of Poverty. Longman Publisher.

Gertler, M. (2001). Rural Cooperatives And Sustainable Development. Saskatoon SK: Center for the study of cooperatives, University of Suskatchewan.

Gibson, R. (2005). The Role of Cooperatives in Community Economic Development. RID working paper No. 2005-3.

Haan, J., Louter, K., \& Gerard, G. (2003). Innovative Behaviour in India Cooperatives; New Product Development in Traditional Sectors. http://ivo.uvt.nl/fulltext/03oth2_groot.pdf - Accessed May, 2004.

ICA (2007). Values of cooperative. Retrieved April 26, 2010, from http://www.ica.coop/principles.html.

ILO (2001). Promotion of Cooperatives. Geneva: International Labour Office. Report V: (1).

International Cooperative Alliance (1895). Statement on the Cooperative Identity. ICA, Geneva. Available online at: http://www.coop.org/coop/principles.html. Retrieved on: April 4, 2009.

Lawal, T. O. (2006). Introduction to Modern Cooperative Management, Akure, Alibi-Eyo \& Co Ltd.

Mukarugwiza, E. (2010). The Hope for Rural Transformation: A Rejuvenating Cooperative Movement in Rwanda. Dares Salaam: International Labour Office.

National Planning Commission (2006). Quarterly Economic Performance Review. Abuja, Nigeria. April/July, p. 70.

Ndifon, H. M., Agube, E. I., \& Odock, G. N. (2012). Sustainability of agricultural cooperative societies in Nigeria: the case of South-South zone, Nigeria. Mediterranean Journal of Social Sciences, 3(2), 19-25.

Philp, R. P., Haynes, P. J., \& Helms, M. M. (1992), Financial service strategies on neglected niches, International Journal of Bank Marketing, 10(2), 25-38. https://doi.org/10.1108/02652329210012131

Reeves, M. (2003). A Wealth of Opportunities in a World of Limits: Free Enterprises. Economics of Cooperation, Federal Reserve Bank of Dallas; www.dallasfed.org

Udoh, E. J. (2008). Estimation of Loan Default among Beneficiaries of a State Government Owned Agricultural Loan Scheme, Nigeria. J. Cent. Europ. Agric., 9(2), 343-352.

United Nations Department of Economic and Social Affairs (UNDESA) (1999). Status and Role of Cooperatives in the Light of New Economic and Social Trends. UN Report.

UWCC (2002). Cooperatives. University of Wisdom Center for Cooperative. Available online at: http://www.uwcc.com.

\section{Copyrights}

Copyright for this article is retained by the author(s), with first publication rights granted to the journal.

This is an open-access article distributed under the terms and conditions of the Creative Commons Attribution license (http://creativecommons.org/licenses/by/3.0/). 